\title{
Phenotypic and genetic evaluation of human monocyte-derived dendritic cells generated from whole blood for immunotherapy
}

\author{
Yousri M. Hussein ${ }^{1}$, Doaa M. Hendawy ${ }^{1 *}$ (D), Abdalrahman N. Alghamdy ${ }^{2}$ and Nermin Raafat ${ }^{1}$
}

\begin{abstract}
Background: Dendritic cells (DCs) recognize different pathogens and cancer cells and activate the adaptive immune response. The generation of effective DC-based cancer vaccines depends on the appropriate differentiation of monocytes in vitro. This study aimed to standardize a protocol for the in vitro differentiation of human peripheral blood monocytes into immature DCs upon treatment with growth factors and generate monocyte-derived DCs (MoDCs). Peripheral blood mononuclear cells were separated from peripheral blood. After monocyte enrichment by plastic adhesion, monocytes were cultured for 6 days in the presence of granulocytemacrophage colony-stimulating factor and interleukin-4 to generate immature DCs. The cells were examined by microscopy. Using flow cytometry, DCs were evaluated for the expression of the CD83 and HLA-DR surface antigens, for the uptake of fluorescein isothiocyanate conjugated dextran, and also for the expression of CD80 and CD86 mRNA.

Results: CD80 and CD86 genes expression was upregulated at day six and exhibited a significant difference $(P<$ 0.05). DCs showed positive expression of the CD83 and HLA-DR surface antigens by flow cytometry and FITCconjugated dextran uptake.

Conclusion: This study represents a preliminary trial to generate immature MoDCs in vitro from blood monocytes collected by the flask adherence method. It offers a panel of surface markers for DCs characterization and provides Immature DCs for experimental procedures after 6 incubation days.
\end{abstract}

Keywords: Adherence, Monocyte-derived, Cell separation, Dendritic cell, Phenotype

\section{Background}

Dendritic cells (DCs) recognize and uptake various antigens, including tumors and viruses in peripheral tissue. Once activated, they migrate to lymph nodes, where they initiate an adaptive immune response. To achieve this, DCs process the engulfed antigens into peptides, which are presented on major histocompatibility complex (MHC) molecules. Peptides loaded onto MHC II

\footnotetext{
* Correspondence: do3a2mahmood@yahoo.com

'Medical Biochemistry \& Molecular Biology Department, Faculty of Medicine, Zagazig University, Zagazig, Egypt

Full list of author information is available at the end of the article
}

molecules are recognized by antigen-specific CD4+ T helper cells. Similarly, peptides loaded onto MHC I molecules are recognized by antigen-specific CD8+ T cells, leading to their proliferation and activation of cytotoxic activity [1].

DCs may be categorized as immature and mature according to their morphology and function. Once foreign antigens are presented to the pattern recognition receptors (e.g., toll-like receptors, C-type lectins, or complement receptors) expressed on the cell membrane, iDCs undergo changes and maturation.

\section{Springer Open}

(-) The Author(s). 2021 Open Access This article is licensed under a Creative Commons Attribution 4.0 International License, which permits use, sharing, adaptation, distribution and reproduction in any medium or format, as long as you give appropriate credit to the original author(s) and the source, provide a link to the Creative Commons licence, and indicate if changes were made. The images or other third party material in this article are included in the article's Creative Commons licence, unless indicated otherwise in a credit line to the material. If material is not included in the article's Creative Commons licence and your intended use is not permitted by statutory regulation or exceeds the permitted use, you will need to obtain permission directly from the copyright holder. To view a copy of this licence, visit http://creativecommons.org/licenses/by/4.0/. 
During this maturation process, antigen uptake receptors are downregulated, whereas antigen presentation molecules are upregulated. Mature DCs express the major histocompatibility complexes I and II in addition to the co-stimulatory molecules CD80 and CD86, which mediate antigen presentation and $\mathrm{T}$ lymphocyte activation [2].

DCs stimulate adaptive immunity and are widely used for cancer immunotherapy, particularly in DC vaccination. With DC-based vaccines, cancer patients are injected with mature tumor antigen-loaded DCs, which are prepared ex vivo. These specialized cells stimulate cytotoxic tumor-specific $\mathrm{T}$ lymphocytes that eliminate cancer cells and induce memory to prevent further cancer growth and recurrence [3].

This study aims to provide an effective strategy to generate DCs from human blood monocytes collected using the immunotherapy flask adherence method.

\section{Methods}

This study was conducted in the Medical Biochemistry Department, and written informed consent was obtained from all participants.

\section{Peripheral blood mononuclear cell (PBMC) isolation}

Fresh peripheral blood $(100 \mathrm{ml})$ was collected from 20 healthy donors under complete aseptic conditions (laminar flow work area). Heparinized blood was diluted 1:1 with phosphate buffer saline (PBS) (Sigma, USA) in 15 $\mathrm{ml}$ Falcon tubes. Using a sterile plastic Pasteur pipette, the diluted blood was layered entirely onto an identical volume of a density gradient containing $5.6 \%$ Ficoll reagent and $9.6 \%$ diatrizoate with a density of $1.077 \mathrm{~g} / \mathrm{ml}$ and an osmolarity of 300 mOsm. We situated falcon tubes at a $45^{\circ}$ angle, allow diluted blood to run down the side of the tube without allowing the two solutions to $\operatorname{mix}[4]$.

Samples were centrifuged for $30 \mathrm{~min}$ at $400 \times g$ at room temperature. PBMCs were collected and washed twice with PBS, and 2\% heat-inactivated FCS solution (Invitrogen, Grand Island, NY, USA) (PBS/2\% FCS) centrifuged for $10 \mathrm{~min}$ at $400 \times g$, and the PBMC pellet was collected at the bottom.

\section{PBMC viability, counting, and culture}

The pellet was resuspended in $2 \mathrm{ml}$ of RPMI (Sigma, Catalog. no. R8758, USA) and counted by hemocytometer. The cells were tested for viability by trypan blue exclusion (Merck Darmstadt, Germany). A total of $1 \times 10^{6}$ cells per $\mathrm{ml}$ were cultured in RPMI-1640 containing $10 \%$ fetal calf serum and $2 \%$ penicillin-streptomycin (Gibco, Catalog. no. 15140-122, USA), then placed in a 6-well plate, containing $50 \mathrm{ng} / \mathrm{ml}$ of GM-CSF (R\&D Systems, catalog no 215-GM, Minneapolis, USA) and $10 \mathrm{ng} / \mathrm{ml}$ of IL-4 (R\&D Systems, catalog no 204-IL, Minneapolis, USA). The 6-well plate was incubated for two hours at $37^{\circ} \mathrm{C}$ in a humidified, $5 \%$ $\mathrm{CO}_{2}$ atmosphere. After $2 \mathrm{~h}$, the non-adherent cells were removed.

\section{Preparation of monocyte-derived DCs}

A fresh medium enriched with GM-CSF and IL-4 was added to the culture. We used an inverted microscope at $\times 400$ magnification power to examine the adherent cells in order to detect monocytes. Every 2 days, complete fresh media was added to the monocytes to generate the immature monocyte-derived DCs (MoDCs). After culturing for 6 days, iDCs were developed.

\section{Characterization of monocyte-derived DCs (MoDCs) Phenotypic analysis of DC by flow cytometry}

DCs were stained with specific monoclonal antibodies CD83-PE and HLA-DR-FITC surface markers (eBiosciences, USA). One hundred microliters of cells at $75 \times$ $10^{3} / \mathrm{ml}$ were incubated in the dark for 30-45 min with $20 \mu \mathrm{l}$ of FITC-conjugated antibodies at $4{ }^{\circ} \mathrm{C}$. The cells were washed with cold phosphate buffer saline (PBS), fixed in $1 \%$ formaldehyde, and resuspended in $200 \mu \mathrm{l}$ PBS (Applied Biosystems) [5].

\section{FITC-dextran assay}

Cells were harvested in a fresh complete culture medium containing $0.5 \mathrm{mg} / \mathrm{mL}$ FITC-dextran (Sigma, St. Louis, $\mathrm{MO}$, USA) and incubated for $30 \mathrm{~min}$ at $5 \% \mathrm{CO}_{2}$ and 37 ${ }^{\circ} \mathrm{C}$ (negative control was incubated on ice) to evaluate the ability of DCs regarding the uptaking of soluble antigens from the culture medium. The uptake was stopped by adding cold PBS with 1\% FCS. Then, the cells were washed four times using a refrigerated centrifuge and then analyzed by flow cytometry [6].

\section{Quantitative real-time PCR for measuring CD80 and CD86 gene expression}

Total RNA was extracted from cultured cells using a kit obtained from (iNtRON Biotechnology, South Korea). RNA was reverse-transcribed to cDNA using the TIAG EN Fast Quant RT Kit (with gDNase). The primers (Biolegio, Nijmegen, Netherlands) sequences used were as follows: CD80 [7] forward 5' - CATCCAAGTGTCCATA CСТC $-3^{\prime}$ and reverse 5-СТCТСАТТССТССТTCTC TC-3' ${ }^{\prime}$, for CD86 [8] forward 5' - TGGTGCTGCTCCTC TGAAGATTC-3' and reverse ${ }^{\prime}{ }^{\prime}$-ATCATTCCTG TGGGCTTTTTGTG- $3^{\prime}$, and $\beta$-actin [9], forward $5^{\prime}$ GGT TCC GCT GCC CTG AGG-3' and reverse 5' GTC CAC GTC ACA CTT CATG-3'. The amplification was done using qPCR (Stratagene Mx3005P) with the following protocol: initial denaturation and polymerase activation at $95{ }^{\circ} \mathrm{C}$ for $30 \mathrm{~s}$. For CD86, 40 cycles of denaturation at $95{ }^{\circ} \mathrm{C}$ for $15 \mathrm{~s}$ were done, followed by 
annealing and elongation at $67{ }^{\circ} \mathrm{C}$ for $1 \mathrm{~min}$. For CD80, 40 cycles of denaturation at $95{ }^{\circ} \mathrm{C}$ for $15 \mathrm{~s}$ were done, followed by annealing and elongation at $63{ }^{\circ} \mathrm{C}$ for $1 \mathrm{~min}$. Relative changes in gene expression were calculated using the $2^{-\Delta \Delta C t}$ method, as described by Livak and Schmittgen [10].

\section{Statistical analysis}

The collected data were statistically analyzed using the SPSS program (Statistical Package for Social Science) version 20. Quantitative data were expressed as the mean \pm SD (standard deviation). The paired sample $t$ test was considered statistically significant at $P$-values < 0.05 , highly statistically significant at $P$-values $<0.001$, and non-significant at $P$-values $>0.05$.

\section{Results}

\section{Morphological characterization of cultured monocytes} and DCs by inverted microscope

Microscopic examination of the mononuclear cells obtained by Ficoll-Hypaque gradient centrifugation from fresh blood samples was tested on day 0 of the experiment. The cell counting and viability of PMNC and monocytes were evaluated in the Table 1. Monocytes were spherical and rounded. They were large in size and contained a large nucleus (Fig. 1a). Morphological examination of DCs was done on the seventh day.

\section{Biochemical results}

\section{Immunophenotypic analysis of DCs by flow cytometry}

DCs (gated cells) showed positive CD83 and HLA-DR expression. The measured mean fluorescent intensity $(\mathrm{MFI}) \pm \mathrm{SD}$ for three experiments was $105 \pm 4.3$ for CD83 and $95 \pm 3.4$ for HLA-DR. Each value is the mean of 3 performed experiments \pm SD (Fig. 2a-c).

\section{Antigen uptake assay}

DCs express mannose receptors which facilitate dextran endocytosis and enable their active uptake to reflect the endocytic antigen capacity. The data revealed that DCs exhibited a high ability to incorporate FITC-dextran; the mean value of uptake capacity \pm SD was $64 \pm 2.3 \%$ (Fig. 3a-d).

\section{Quantitative real-time PCR analysis of CD80 and CD68 genes}

The expression of CD80 and CD86 mRNA was assessed by qRT-PCR relative to $\beta$-actin expression. The result demonstrated a significant upregulation in the expression of both CD80 and CD86 in DCs compared with untreated monocytes. The mean value \pm SD of CD80 and CD86 in DCs relative to monocytes was $2.5 \pm$ 0.532 and $4 \pm 0.42$, respectively (Fig. 4 ).

\section{Discussion}

DCs exhibit the highest potency for antigen uptake and presentation among the immune cells [11, 12]. They show many immune regulation features that balance the complex system of inflammatory and inhibitory immune reactions in the tumor tissue microenvironment [13]. DCs are involved in innate and adaptive immunity. They can modulate immune function, reverse immunosuppression, and decrease cancer immunotolerance [14].

Human monocytes isolated from PBMCs differentiate to produce iDCs so that DCs are usually generated from blood monocytes in vitro. iDC maturation to mature DCs occurs through an antigen-loading step [15].

Human DCs are loaded with recombinant proteins, lysates of tumor cells, or peptides, the latter representing the most common process [16].

$\mathrm{DC}$ vaccines aim to stimulate cancer-specific effector $\mathrm{T}$ cells to eradicate tumor cells and to stimulate immunological memory to control cancer recurrence [16]. Peptide-loaded DCs can present Ags to naïve T lymphocytes [17]. The proliferative and cytolytic function of tumor-specific cytotoxic $\mathrm{T}$-lymphocytes requires $\mathrm{Ag}$ identification by the $\mathrm{T}$ cell receptor (TCR). These antigens are linked to MHC class I molecules on APCs [16].

This study evaluated the DC generation from monocytes isolated from whole peripheral blood for immunotherapy in an in vitro model. These DCs were isolated using Ficoll-Hypaque gradient centrifugation.

There are multiple methods for collecting monocytes from whole peripheral blood, including flask adherence [18], density gradient centrifugation [19], and separations using a specific marker such as magnetic-activated cell sorting [2] or monocytes separation by bipolar tetrameric antibody [20]. In our study, we used the flask adhesion method for monocyte separation. Delirezh and Shojaeefar [21] demonstrated that magnetic-activated cell sorted monocytes' viability was slightly higher than Flask-DCs. They express higher levels of CD14 ${ }^{-}$compared with Flask-DCs but a higher IFN- $\gamma$ to IL-4 ratio, IL-12, and an IL-12 to IL-10 ratio in the flask group. Also, Flask-DCs polarized the immune response toward a Th1 cytokine profile and cell-mediated immunity, a desired feature in cancer immunotherapy.

Table 1 The cell count and viability of peripheral blood mononuclear cells and monocytes at day 0

\begin{tabular}{llll}
\hline & Cell count (cells/ml) & Mean \pm SD & Viability $\%$ \\
\hline Mononuclear cells & 5 to $5.0 \times 10^{7}$ & $5.0 \times 10^{7} \pm 0.52$ & $95-98$ \\
Monocytes & 5 to $15 \times 10^{5}$ & $10 \times 10^{5} \pm 3.251$ & $70-75$ \\
\hline
\end{tabular}




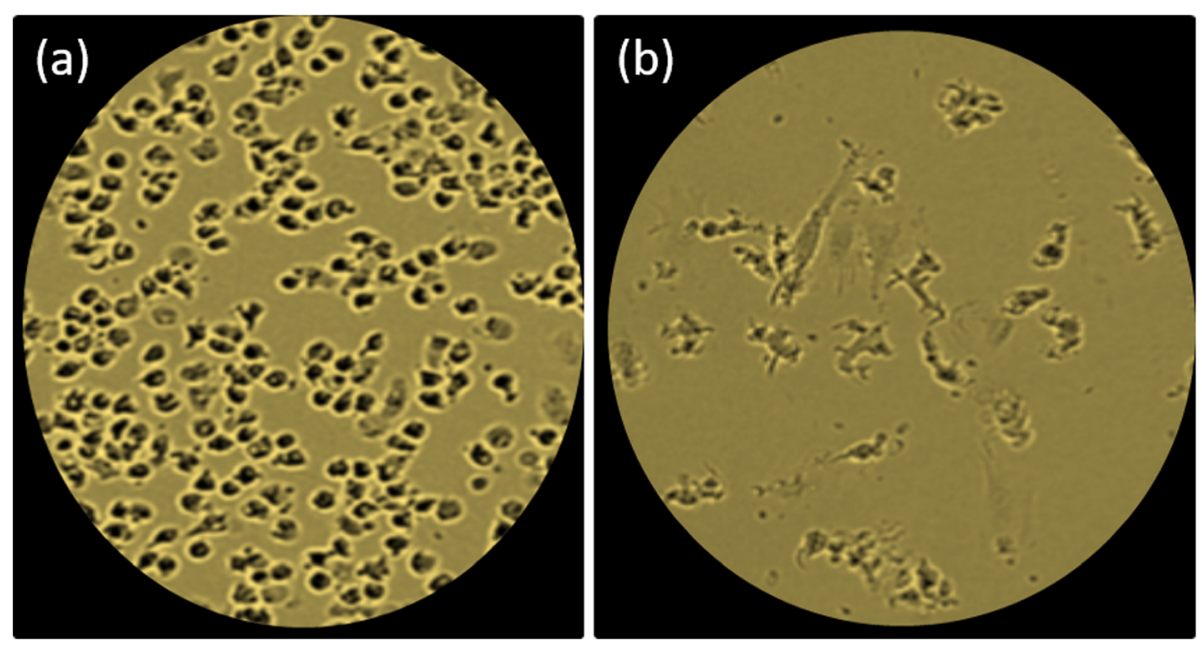

Fig. 1 Microscopic image showing morphological changes during in vitro culture of monocytes and the generation of dendritic cells $(\times 40)$. a Morphologic appearance of cultured adherent monocytes on day 0; the cells were small and rounded with a large nucleus. b Generated immature DCs on the day; cells were semi-adherent with multiple projections

For MoDC generation through human monocytes isolation, Posch et al. [2] used the anti-human CD14 magnetic nanoparticle for the positive selection of CD14 leukocytes. The advantages of this technique compared with other protocols are the high purity and speed. MoDCs are the most popular model used for DC generation because the direct isolation of DCs from biopsies or cord blood $\mathrm{CD}_{34}{ }^{+}$stem cells is a more complex technique. Also, it leads to inefficient cell numbers.

Elkord et al. [22] showed that the positive selection of monocytes by anti-CD14 coated microbeads inhibits lipopolysaccharide (LPS)-induced production of IL-12, IL-10, and TNF- $\alpha$ from DCs. However, for Flask-DCs, LPS induced much higher levels of IL-12, IL-10, and TNF- $\alpha$ cytokines and CTLs.
DCs were phenotypically and genetically confirmed. HLA-DR, CD 83, and dextran uptake were detected by flow cytometry. Also, the expression of CD80 and CD86 genes was measured by quantitative real-time PCR.

Our results demonstrated DC-positive expression of CD83 and HLA-DR by flow cytometry, DCs showed high positive uptake of dextran and significant upregulation of CD80 and CD86 genes expression in DCs compared to monocytes.

Pan et al. [23] and Elkord et al. [24] reported similar findings.

Pan et al. [24] observed positive CD83 and HLA-DR and positive expression of CD80 and CD86. In their model, PBMCs were isolated from healthy donors' peripheral blood using Ficoll-Hypaque gradient centrifugation, and the monocytes were separated by the flask

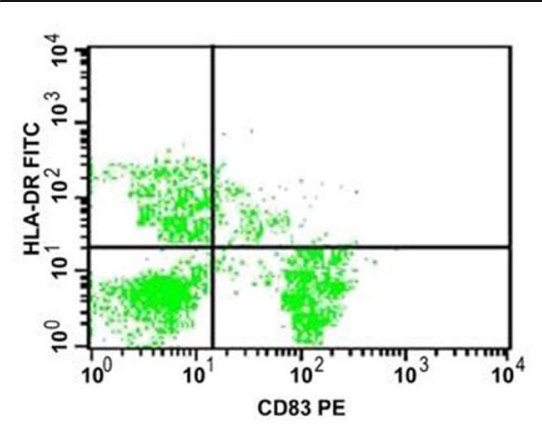

A

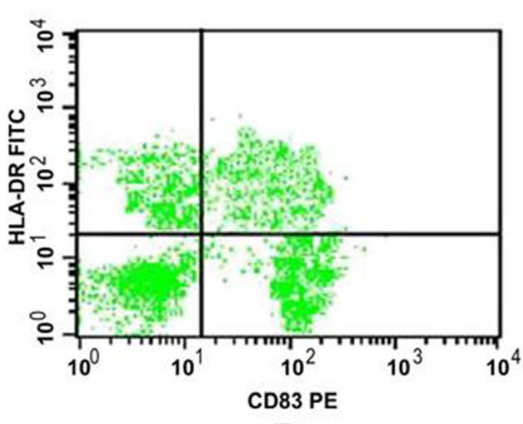

B

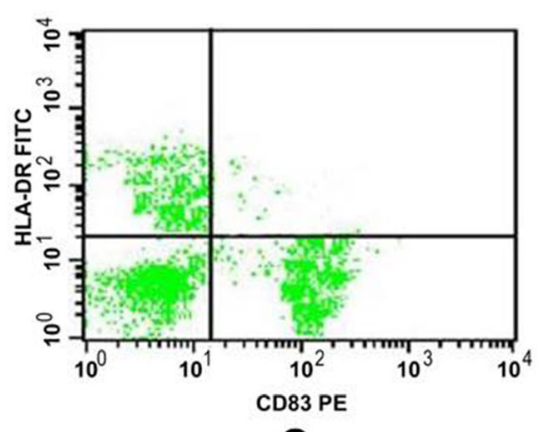

C

Fig. 2 The expression of CD83 PE (lower right) and HLA-DR FITC (upper left) on dendritic cells by flow cytometry; dendritic cells (gated cells) showed positive surface expression of CD83 and HLA-DR 

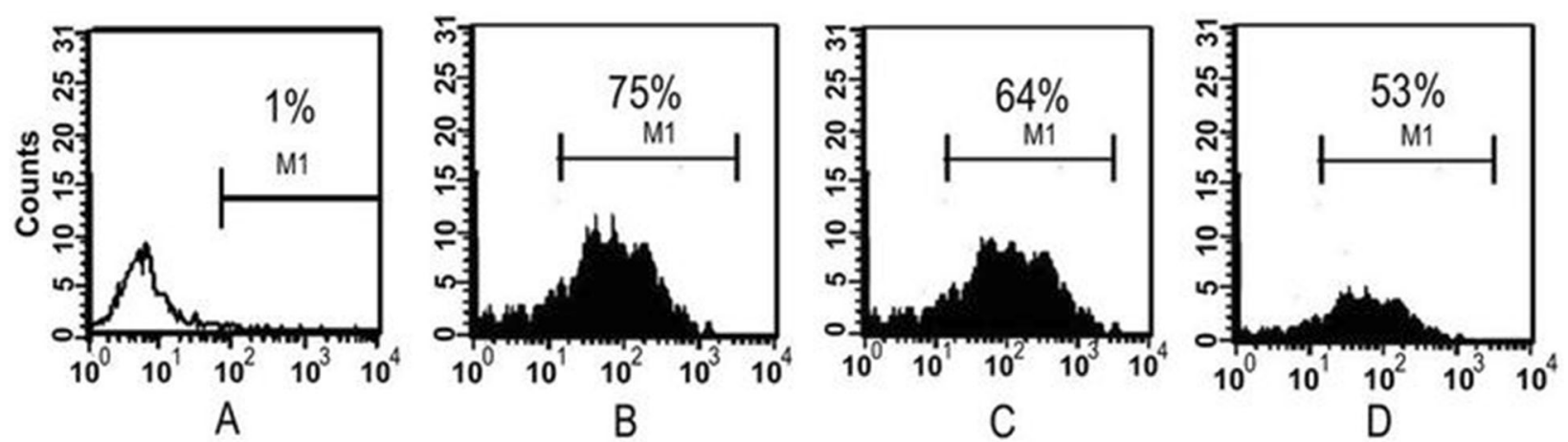

Fig. 3 Active uptake FITC-dextran by dendritic cells; a Dextran uptake by monocytes (control). b-d First, second, and third experiments of evaluation of dextran uptake by dendritic cells, respectively

adherence method. Non-adherent cells (T cells) were removed. Monocytes were harvested with media enriched with IL-4 $(400 \mathrm{U} / \mathrm{ml})$ and GM-CSF $(1000 \mathrm{U} / \mathrm{ml})$ to produce DCs under conditions identical to our study.

Elkord et al. [22] demonstrated that monocytes exhibit lower levels of CD14 expression and higher levels of HLA-DR and CD86 expression. iDCs express CD1a and low levels of CD80 on their cell surface but do not express CD83.

Our study used IL-4 and GM-CSF at concentrations of $10 \mathrm{ng} / \mathrm{mL}$ and $50 \mathrm{ng} / \mathrm{mL}$, respectively, and the cells were cultivated for 6 days, consistent with El-Sahrigy et al. [23]. They demonstrated that iDCs were generated by culturing monocytes selected by the flask adhesion method and examining their viability. The gated cells
(iDCs) showed positive CD1a, HLA-DR, CD11c, and CD83 expression. The monocyte culture media was enriched with $50 \mathrm{ng} / \mathrm{ml} \mathrm{GM-CSF}$ and $20 \mathrm{ng} / \mathrm{ml} \mathrm{IL-4.}$

However, Colić et al. [25] provided evidence that GMCSF $(100 \mathrm{ng} / \mathrm{ml})$ with IL-4 $(5 \mathrm{ng} / \mathrm{ml})$ was effective in iDC generation from monocytes at the same concentration of GM-CSF and ten times higher concentration of IL-4 $(50 \mathrm{ng} / \mathrm{ml})$. iDCs were characterized by HLA-DR, CD80, CD86, and CD1a positive expression and downregulation of CD14 and an absence of CD83. At lower concentrations of IL-4, a high number of cells were adherent, and DC generated at low concentrations of IL-4 (5 $\mathrm{ng} / \mathrm{ml}$ ) showed more robust anti-tumor capacity against the Jurkat cell line than DC generated at higher IL-4 concentrations. Adherent cells cultured with only

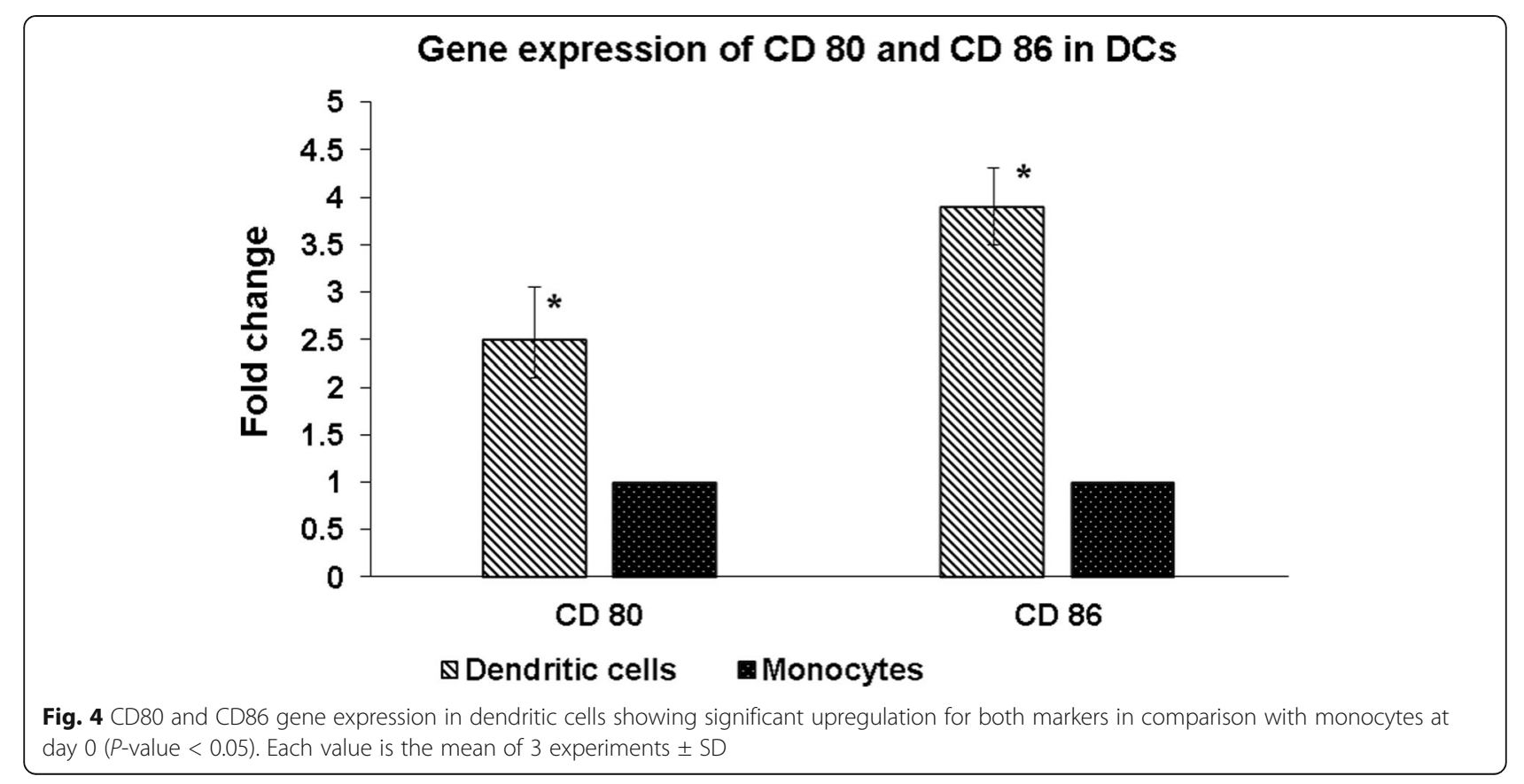


GM-CSF were primarily macrophages, as confirmed by CD14-positive expression.

El Ashmawy et al. [26] reported that cultured cells were supplemented with GM-CSF $(20 \mathrm{ng} / \mathrm{mL})$ and IL-4 $(20 \mathrm{ng} / \mathrm{mL})$. Cells were characterized by morphological change and appeared to be semi-adherent with branched projections, and they showed positive expression of CD83 and CD86 on the cell surface.

Other researchers used variable growth factor concentrations, and their trials were successful regarding DC generation. The concentrations were as follows: GMCSF $50 \mathrm{ng} / \mathrm{ml}$ and IL-4 $50 \mathrm{ng} / \mathrm{ml}$ [27], GM-CSF $100 \mathrm{ng} /$ $\mathrm{ml}$ and IL-4 $20 \mathrm{ng} / \mathrm{ml}$ [28], GM-CSF $100 \mathrm{ng} / \mathrm{ml}$ and IL-4 $20 \mathrm{ng} / \mathrm{ml}$ [29], and GM-CSF $10 \mathrm{ng} / \mathrm{ml}$ and IL-4 $20 \mathrm{ng} /$ $\mathrm{ml}[30]$.

In our study, we cultured the cells in a 6-well culture plate. Each well contained $4 \mathrm{ml}$ of culture media (RPMI1640 containing 10\% FCS, $2 \%$ penicillin-streptomycin with GM-CSF $(50 \mathrm{ng} / \mathrm{mL})$ and IL-4 $(10 \mathrm{ng} / \mathrm{mL}))$. Tkachenko et al. [31] used different media for the generation of iDCs. They used RPMI 1640 with $2 \%$ human serum albumin, RPMI 1640 with $2 \% \mathrm{TCH}$ serum replacement, Panserin 501, and X-VIVO 15. Flow cytometry showed that in all previous media, the iDCs were CD45+ CD83+ and lost CD14.

Our results were also in line with Osugi et al. [32], who reported that MoDCs derived in in vitro culture did not express the CD1a surface antigen but expressed high levels of the HLA-DR CD86, CD83, and CD40 surface antigens. Kolli et al. [29] also characterized the phenotype of DCs by flow cytometry for other surface markers, including MHC class II, CD11b, CD11c, CD86, and CD80.

DCs have mannose receptors on their cell membrane that facilitates dextran uptake and phagocytosis [33]. In a functional study of DCs using FITC-dextran, we demonstrated that DCs showed a high capacity for FITCdextran uptake, which is in line with Encabo et al. [6], who confirmed that fresh monocytes and immature MODCs showed an increased ability for accumulating FITC-dextran. After exposure to TNF- $\alpha$ for 2 days, mature Mo-derived DCs reduced their ability to internalize FITC-dextran.

\section{Conclusion}

In conclusion, we revealed that the flask adherence method is a successful procedure for mediating monocytes differentiation into immature MoDCs, which are efficient for experimental studies after 6 incubation days. Further studies are recommended for the study of monocyte differentiation kinetics into DCs. Also, further maturation of iDCs is recommended for the use of mature DCs in DC tumor vaccines.

\section{Abbreviations}

APCs: Antigen-presenting cells; DCs: Dendritic cells; MHC: Major

histocompatibility complexes; iDCs: Immature dendritic cells; PBS: Phosphatebuffered saline; FCS: Fetal calf serum; RPMI: Roswell Park Memorial Institute; GM-CSF: Granulocyte monocyte colony-stimulating factor; IL: Interleukin; PBMCs: Peripheral blood mononuclear cells; MoDCs: Monocyte-derived DCs; FITC: Fluorescein isothiocyanate; MFI: Mean fluorescent intensity; RTqPCR: Quantitative real-time PCR; CTLs: Cytotoxic T Iymphocytes; TCR: T cell receptor; LPS: Lipopolysaccharide; TNF-a: Tumor necrosis factor-alpha

\section{Acknowledgements}

Not applicable

\section{Authors' contributions}

YMH and NR prepared the idea and designed the study. ANA did the data statistical analysis. DMH and NR performed all the laboratory investigations. All authors wrote, read, and approved the final manuscript.

Funding

Not applicable

Availability of data and materials

Not applicable

\section{Declarations}

Ethics approval and consent to participate

This study has been approved by the Faculty of Medicine, Zagazig University, Institutional Review Board (IRB) (reference number is 4464/13-3-2018).

Written informed consents were obtained from all participants.

Consent for publication

Not applicable

Competing interests

The authors declare that they have no competing interests.

\section{Author details}

${ }^{1}$ Medical Biochemistry \& Molecular Biology Department, Faculty of Medicine, Zagazig University, Zagazig, Egypt. ${ }^{2}$ Community Medicine Department Faculty of Medicine, Taif University, Taif, Saudi Arabia.

Received: 15 December 2020 Accepted: 8 April 2021

Published online: 25 May 2021

\section{References}

1. Embgenbroich M, Burgdorf S (2018) Current concepts of antigen crosspresentation. Front. Immunol. 9:1643. https://doi.org/10.3389/fimmu.2018.01 643

2. Posch W, Lass-Flörl C, Wilflingseder D (2016) Generation of human monocyte-derived dendritic cells from whole blood. J. Vis. Exp. (118): e54968

3. Bol KF, Schreibelt G, Rabold K, Wculek SK, Schwarze JK, Dzionek A, Teijeira A, Kandalaft LE, Romero P, Coukos G, Neyns B, Sancho D, Melero I, de Vries IJM (2019) The clinical application of cancer immunotherapy based on naturally circulating dendritic cells. J Immunother Cancer 7(1):109

4. Mallone R, Mannering SI, Brooks-Worrell BM, Durinovic-Belló I, Cilio CM, Wong FS, Schloot NC, T-Cell Workshop Committee and Immunology of Diabetes Society (2011) Isolation and preservation of peripheral blood mononuclear cells for analysis of islet antigen-reactive T cell responses: a position statement of the T-Cell Workshop Committee of the Immunology of Diabetes Society. Clin Exp Immunol 163(1):33-49

5. Raafat N, Sadowski-Cron C, Mengus C, Heberer M, Spagnoli GC, Zajac P (2012) Preventing vaccinia virus class-I epitopes presentation by HSV-ICP47 enhances the immunogenicity of a TAP-independent cancer vaccine epitope. Int J Cancer 131(5):E659-E669

6. Encabo A, Solves P, Mateu E, Sepúlveda P, Carbonell-Uberos F, Miñana MD (2004) Selective generation of different dendritic cell precursors from CD34 + cells by interleukin-6 and interleukin-3. Stem Cells. 22(5):725-740. https:// doi.org/10.1634/stemcells.22-5-725 
7. Wang L-X, Mei Z-Y, Zhou J-H, Yao Y-S, Li Y-H, Xu Y-H, Li J-X, Gao X-N, Zhou M-H, Jiang M-M, Gao L, Ding Y, Lu X-C, Shi J-L, Luo X-F, Wang J, Wang L-L, Qu C, Bai X-F, Yu L (2013) Low dose decitabine treatment induces CD80 expression in cancer cells and stimulates tumor-specific cytotoxic T lymphocyte responses. PLoS ONE 8(5):e62924. https://doi.org/10.1371/journa I.pone.0062924

8. Suzuki M, Shinohara F, Sato K, Taniguchi T, Takada H, Rikiishi H (2003) Interleukin-1b converting enzyme subfamily inhibitors prevent induction of CD86 molecules by butyrate through a CREB-dependent mechanism in HL60 cells. Immunology 108(3):375-383. https://doi.org/10.1046/j.1365-2 567.2003.01597.x

9. De Carlo F, Witte TR, Hardman WE, Claudio PP (2013) Omega-3 eicosapentaenoic acid decreases CD133 colon cancer stem-like cell marker expression while increasing sensitivity to chemotherapy. PLoS One 8:1-12

10. Livak KJ, Schmittgen TD (2001) Analysis of relative gene expression data using real-time quantitative $P C R$ and the $2 \wedge-\Delta \Delta C T$ method. Methods $25(4)$ : 402-408. https://doi.org/10.1006/meth.2001.1262

11. Noh YW, Jang YS, Ahn KJ, Lim YT, Chung BH (2011) Simultaneous in vivo tracking of dendritic cells and priming of an antigen-specific immune response. Biomaterials. 32(26):6254-6263. https://doi.org/10.1016/j.bioma terials.2011.05.013

12. Peng $W$, Zhao G, Ma Y, Yu H, Wang X (2011) Dendritic cells transfected with PEG10 recombinant adenovirus elicit an anti-tumor immune response in vitro and in vivo. Vaccine. 29(18):3501-3506. https://doi.org/10.1016/j.va ccine.2011.02.027

13. Mineharu Y, Castro MG, Lowenstein PR, Sakai N, Miyamoto S (2013) Dendritic cell-based immunotherapy for glioma: multiple regimens and implications in clinical trials. Neurologia Medico-Chirurgica 53(11):741-754. https://doi.org/10.2176/nmc.ra2013-0234

14. Jie X, Hua L, Jiang W, Feng F, Feng G, Hua Z (2012) Clinical application of a dendritic cell vaccine raised against heat-shocked glioblastoma. Cell Biochem Biophys 62(1):91-99. https://doi.org/10.1007/s12013-011-9265-6

15. Gilboa E (2007) DC-based cancer vaccines. J Clin Invest. 117(5):1195-1203. https://doi.org/10.1172/JCl31205

16. Choi YJ, Park S-J, Park Y-S, Park HS, Yang KM, Heo K (2018) EpCAMpeptideprimed dendritic cell vaccination confers significant anti-tumor immunity in hepatocellular carcinoma cells. PLoS ONE 13(1):e0190638. https://doi.org/1 0.1371/journal.pone.0190638

17. Wierecky J, Mueller M, Brossart P (2006) Dendritic cell-based cancer immunotherapy targeting MUC-1. Cancer Immunol Immunother. 55(1):6367. https://doi.org/10.1007/s00262-005-0673-6

18. Davis GE (1992) The Mac-1 and p150/95 beta 2 integrins bind denatured proteins to mediate leukocyte cell-substrate adhesion. Exp Cell Res 200(2): 242-252. https://doi.org/10.1016/0014-4827(92)90170-D

19. Lehner M, Holter W (2002) Endotoxin-free purification of monocytes for dendritic cell generation via discontinuous density gradient centrifugation based on diluted Ficoll-Paque Plus. Int Arch Allergy Immunol 128(1):73-76. https://doi.org/10.1159/000058006

20. Mucci I, Legitimo A, Compagnino M, Consolini R, Migliaccio P, Metelli MR, Scatena F (2009) The methodological approach for the generation of human dendritic cells from monocytes affects the maturation state of the resultant dendritic cells. Biologicals 37(5):288-296. https://doi.org/10.1016/j. biologicals.2009.05.004

21. Delirezh N, Shojaeefar E (2012) Phenotypic and functional comparison between flask adherent and magnetic activated cell sorted monocytes derived dendritic cells. Iran. J. Immunol 9(2):98-108

22. Elkord E, Paul EW, Howard K, Anthony WR (2005) Human monocyte isolation methods influence cytokine production from in vitro generated dendritic cells. Immunology 114(2):204-212. https://doi.org/10.1111/j.1365-2 567.2004.02076.x

23. El-sahrigy SA, Mohamed NA, Talkhan HA, Abdel Rahman AM (2015) Comparison between magnetic-activated cell sorted monocytes and monocyte adherence techniques for in vitro generation of immature dendritic cells: an Egyptian trial. Centr Eur J Immunol 40, 18(1):-24

24. Pan K, Zhao J, Wang H, Li J, Liang X, Sun J, Chen Y, Ma H, Liu Q, Xia J (2010) Comparative analysis of cytotoxic $T$ lymphocyte response induced by dendritic cells loaded with hepatocellular carcinoma-derived RNA or cel Iysate. Int. J. Biol. Sci. 6(7):639-648. https://doi.org/10.7150/ijbs.6.639

25. Colić M, Jandrić D, Stojić-Vukanić Z, Antić-Stanković J, Popović P, Vasilijić S, Milosavljević P, Balint B (2003) Differentiation of human dendritic cells from monocytes in vitro using granulocyte-macrophage colony-stimulating factor and low concentration of interleukin-4. Vojnosanit Pregl 60(5):531-538. https://doi.org/10.2298/NSP0305531C

26. El-Ashmawy NE, El-Zamarany EA, Khedr EG, El Bahrawy HA, El Feky OA (2018) Antigen-loaded dendritic cells triggers a specific cytotoxic T lymphocytes immune response against hepatocellular carcinoma: in vitro study. Clin Transl Oncol 21:636-645

27. Stocki P, Wang XN, Dickinson AM (2012) Inducible heat shock protein 70 reduces $T$ cell responses and stimulatory capacity of monocyte-derived dendritic cells. J Biol Chem 287(15):12387-12394. https://doi.org/10.1074/jbc M111.307579

28. Zobywalski A, Javorovic M, Frankenberger B, Pohla H, Kremmer E, Bigalke I, Schendel DJ (2007) Generation of clinical grade dendritic cells with the capacity to produce biologically active IL-12p70. J Transl Med 5(1):18-22. https://doi.org/10.1186/1479-5876-5-18

29. Kolli D, Bao X, Liu T, Hong C, Wang T, Garofalo RP, Casola A (2011) Human metapneumovirus glycoprotein G inhibits TLR4-dependent signaling in monocyte-derived dendritic cells. J Immunol 187(1):47-54. https://doi.org/1 0.4049/jimmunol.1002589

30. Jiang $M$, Osterlund $P$, Sarin LP, Poranen MM, Bamford DH, Guo D, Julkunen (2011) Innate immune responses in human monocyte-derived dendritic cells are highly dependent on the size and the 5' Phosphorylation of RNA molecules. J Immunol 187(4):1713-1721. https://doi.org/10.4049/ jimmunol.1100361

31. Tkachenko N, Wojas K, Tabarkiewicz J, Rolinski J (2005) Generation of dendritic cells from human peripheral blood monocytes - comparison of different culture media. Folia Histochem Cytobiol 43(1):25-30

32. Osugi Y, Vuckovic S, Hart DN (2002) Myeloid blood CD11c dendritic cells and monocyte-derived dendritic cells differ in their ability to stimulate $T$ lymphocytes. Blood 100(8):2858-2866. https://doi.org/10.1182/blood.V100. 8.2858

33. Pustylnikov S, Sagar D, Jain P, Khan ZK (2014) Targeting the C-type lectinsmediated host-pathogen interactions with dextran. J Pharm Pharm Sci. 17(3):371-392. https://doi.org/10.18433/J3N590

\section{Publisher's Note}

Springer Nature remains neutral with regard to jurisdictional claims in published maps and institutional affiliations.

\section{Submit your manuscript to a SpringerOpen ${ }^{\circ}$ journal and benefit from:}

- Convenient online submission

- Rigorous peer review

- Open access: articles freely available online

High visibility within the field

- Retaining the copyright to your article

Submit your next manuscript at $>$ springeropen.com 